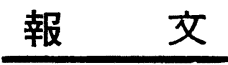

\title{
エステル交換・精製ラード中のナトリウム メトキシド触媒関連化合物の分析
}

\author{
山崎 恵・佐野春樹・堤忠一・高木 徹* \\ 農林省食品総合研究所 (東京都江東区塩浜 1-4-12) \\ * 北海道大学水産学部水産化学科 (函館市港町 3-1-1)
}

\section{Analysis of Compounds Related on a Sodium Methoxide} Catalyst in Interesterified and Refined Oils

\author{
Megumi Yamazaki, Haruki Sano, Chūichi Tsutsumi and Tōru Takagi* \\ National Food Research Institute, Ministry of Agriculture and \\ Forestry (1-4-12, Shiohamacho, Kōtōku, Tokyo) \\ * Faculty of Fisheries, Hokkaido University (3-1-1 Minato-cho, Hakodate)
}

\begin{abstract}
Lards were interesterified with sodium methoxide (s.m) as a catalyst. Methanol from s.m was analyzed in deodorized oil after final refining of interesterified oil by gas chromatography. As the peak of methanol has not been found, it is less than $1 \mathrm{ppm}$ if present. Also, sodium compounds remained in interesterified and refined lards were analyzed by atomic absorption. The degree of oxidation was found to have influence on them. That is, the higher oxidative degree, the more sodium remained. In the steam distillate from deodorization, methyl esters were identified by GC-Mass spect= rometry. It shows the conversion of s.m to the methyl estsrs in the process.
\end{abstract}

\section{1 緒言}

エステル交換反忍は，エステルに反応させる物質によ 门（1）アルコール：アルコーリシス，(2) 酸：アシドリ シス, (3) エステル：エステル置換反応の三種に分類さ れる ${ }^{1), 2)}$ ささら，(3) においては，油脂のエステル交 換反応の際，(i) 無差別型エステル置換反応々，(ii）飽 和脂肪酸グリセリド，不飽和脂肪酸グリセリドのみに片 寄せする指向型エステル置掺反応汇分けられる。食用油 脂工業ではエステル上しての油脂（トリグリ七リド）上 そして他の脂肪酸構成からなる油脂を反応物質として反 忘させ油脂中の脂肪酸分子を分子内及び分子間で相互に 交換させ融点，かたさ等の物理的性質を変化させること を行っている。無差別型エステル交換を行った油脂（ラ 一ドが主）を原料としてマーガリンやショートニングを 加工するとちょう(稠)度幅, クリーミング性, 保型性及 び展延性が改良され，この油脂を使用した菒子，ハンは その品質が向上することが知られている33,4)。

エステル基の交換は，触媒を使用するこ之なしに高温 $\left(230 \sim 260^{\circ} \mathrm{C}\right)$ 加熱によっても可能であるが，長時間 (24h）を要することや遊離脂肪酸が増大寸ることから
通常, 触媒索使用し低温下, 短時間 (30 min 位) で反応 を終了させている。触媒として数種利用されているが， 無差別型エステル交換反応では，一般にナトリウムメト キシドが使用されている4) フ）(日本では食品衛生法に より許可されていない)。

ナトリウムメトキシドは水汇より加水分解し, 水酸化 ナトリウムとメタノールを生じ，さらに二成分は油脂と 反忘し七ッケン及び脂肪酸のメチルエステルを生成す る。食用油脂工業では, 反応終了後, 水洗, 脱色及び脱 臭の各精製工程によりナトリウムメトキシドを除去して いるがその残留の有無を調心゙た報告はない。著者らはナ トリウムメトキシド使用によるエステル交換油脂を調製 し，ナトリウムメトキシドの加水分解物の残留の有無を 調べた。ナトリウム化合物については油脂の酸化度の影 響についても検討したのでここに報告する。

\section{2 実験と結果}

\section{$2 \cdot 1$ 試料}

ラード: 精製ラード（試料 No. 1)

酸化ラード：上記ラードを $60^{\circ} \mathrm{C}$ オーブンで酸化して 得た（試料 No. 2 5)。その特性值は Table-1 のと㧍 
Table-1 Properties of sample oils (Lard).

\begin{tabular}{c|c|c|c}
\hline \multirow{2}{*}{$\begin{array}{c}\text { Sample oil } \\
\text { (number) }\end{array}$} & \multicolumn{3}{|c}{ Property } \\
\cline { 2 - 4 } & POV $^{\mathrm{a}}$ & $\mathrm{CV}^{\mathrm{b}}$ & IV $^{\mathrm{c}}$ \\
\hline 1 & 0 & 7.9 & 71.9 \\
2 & 4.4 & 12.4 & 71.7 \\
3 & 16.1 & 18.1 & 71.5 \\
4 & 28.8 & 23.7 & 71.4 \\
5 & 40.9 & 33.6 & 71.0 \\
\hline
\end{tabular}

a. Peroxide value, b. Carbonyl value, c. Iodine value

りである。

\section{$2 \cdot 2$ ナトリウムメトキシド}

触媒としてのナトリウムメトキシドは鉄興社製を用い た。 $45.1 \mathrm{mg}$ をひょら取し水 $100 \mathrm{ml}$ で溶解後， N/100 塩酸で滴定した結果, ナトリウムメトキシド水溶液 10 $\mathrm{ml}$ 中の水酸化ナトリウム量は $28.16 \mathrm{mg}$ に相当した(純 度 $84.3 \%)$ 。次に GLC $(2 \cdot 5)$ により分析したところ標 準用メタノールと同保持時間にピークを確認した。

\section{$2 \cdot 3$ エステル基交換油脂の調製}

試料油脂 $300 \mathrm{~g}$ を $1 l$ のなす型フラスコに入れ, 乾燥 窒素を吹き込み減圧下 $(2 \mathrm{mmHg}), 110^{\circ} \mathrm{C}$ に加熱し脱水 を行った (30 min)。次に, ナトリウムメトキシドの濃 度が $0.2 \%$ になるように添加し乾燥窒素を吹き込んだ状 態で $80^{\circ} \mathrm{C}, 30 \mathrm{~min}$ 加熱し反応を終了させた。エステル 交換油脂を $1 l$ の分液漏斗に移し，これに水 $300 \mathrm{ml}$ を 加え振とら後静置し下層の水層を除去した。洗液が中性 となったところで水洗在終了した（水洗処理）。水洗処 理油脂を $1 l$ の角フラスコに加え, さらに活性白土を 添加 (油脂に対し $1 \%$ ) し, 乾燥窒素を吹き込み $110^{\circ} \mathrm{C}$, $20 \mathrm{~min}$ 加熱した後, 白土吸着物質を沪別し脱色油脂を 得た (脱色処理)。脱臭は， $1 l$ なす型フラスコに脱色油 脂を加えた後, 真空度 $2 \mathrm{mmHg}$ のもとに水蒸気を導入 し $, 240^{\circ} \mathrm{C}, 1 \mathrm{~h}$ の水蒸気蒸留により行った。蒸留による 留去物質はドライアイスーアセトンで冷却した捕集びん に捕集した。

\section{4 エステル交換油脂の固体脂指数（SFI）}

エステル交換油脂のSFI は，日本油化学協会制定基準 油脂分析試験法 ${ }^{8)}$ に従って測定した。その結果は Fig.-1 に示した。

\section{$2 \cdot 5$ エステル交換油脂中のメタノールの分析}

エステル交換油脂中のメタノールの分析は，プレカラ ム法 ${ }^{9}$ GLC を採用した。プレカラムとして試料気化室 への充てん物は，ガラスビーズを用いたところ感度低下 を招いたことから，グラスウールのみを詰めた。カラム は Porapak Q 100 120 mesh ( $2 \mathrm{~m} \times 3 \mathrm{~mm}$. id) 使用 し, カラム温度は $5^{\circ} \mathrm{C} / \mathrm{min}\left(50 \sim 170^{\circ} \mathrm{C}\right)$ の昇温分析を 行った。

試料油脂 $5 \mathrm{~g}$ を $10 \mathrm{ml}$ 容量フラスコにとり, ペンタ

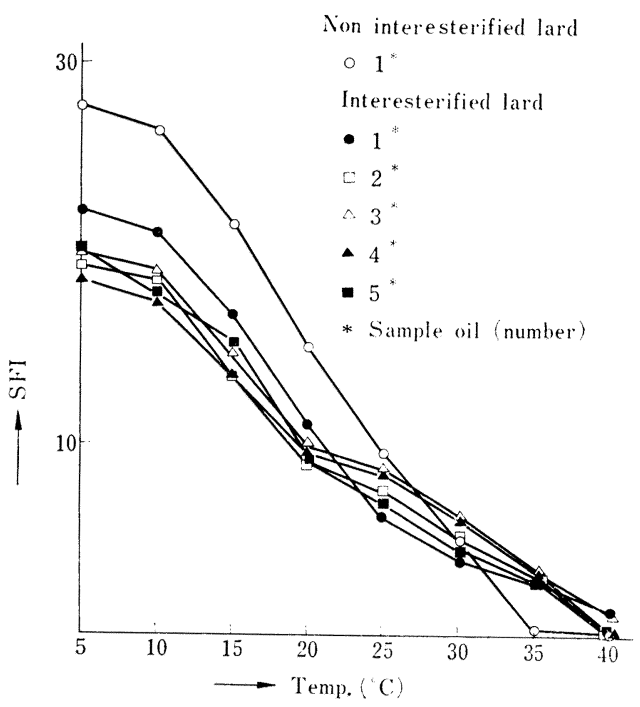

Fig.-1 Dilatometric curves of lard and interesterified lards.

ンで溶解した。また内部標準物質としてエタノールを用 いた。油脂ペンタン溶液 $0.5 \lll$ をガスクロマトグラフ に注入し分析した。GLCによるメタノールの標準曲線 は Fig.-2に，メタノール分析のガスクロマトグラムは

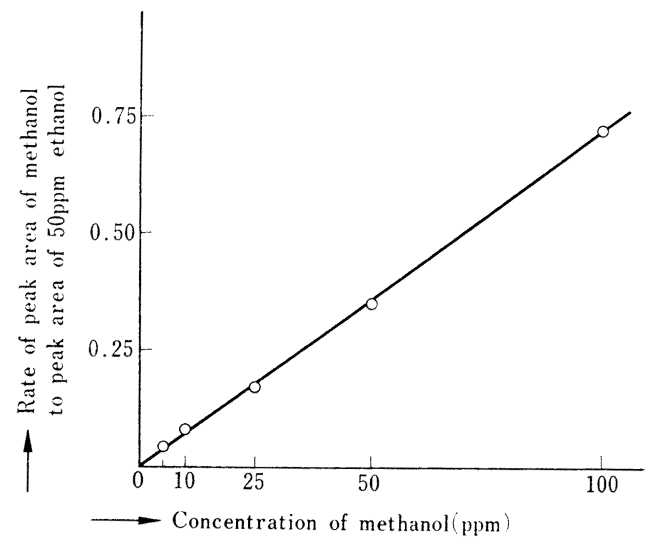

Fig.-2 Calibration curve of methanol.

Fig.-3 に示した（ppm はペンタン溶液中における濃度 を表す)。エステル交換油脂として精製最終の脱臭処理 を経た脱臭油についての分析結果は，Fig.-3 に見られ るようにメタノールのピークを検出することができなか った（検出限界 $1 \mathrm{ppm)。}$

$2 \cdot 6$ エステル 交換 油脂 中 のナトリウム化合物の測 定 $^{10)}$

$100 \mathrm{ml}$ 三角フラスコに試料油脂 $10 \mathrm{~g}$ をょう取し, これに四塩化炭素 $20 \mathrm{ml}$ を加え溶解した。100 ml の分 液漏斗にこの液を移し $1 \%$ 塩酸 $10 \mathrm{ml}$ を加え振とう器 (Iwaki-KM-Shaker) で $5 \mathrm{~min}$ 振とう後，遠沈管に液 


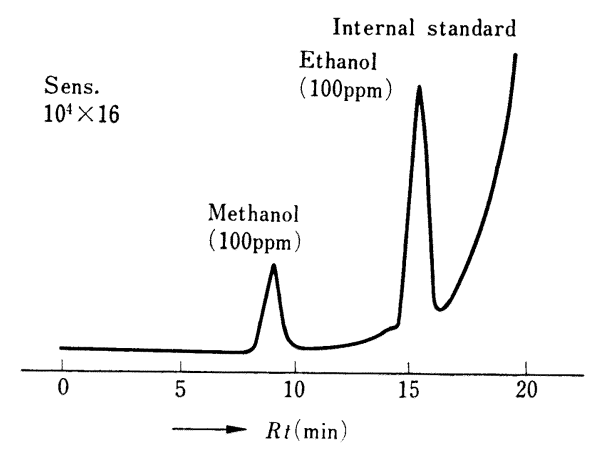

1. Standard solution

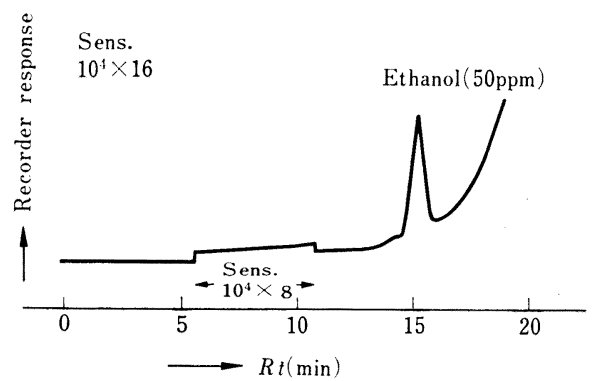

2. Deodorized oil-pentane solution

Fig.-3 Gas chromatograms of methanol.

を移し遠心分離を行った $(1,500 \sim 2,000 \mathrm{rpm})$ 。 ついで $1 \%$ 塩酸の上澄み液中のナトリウムを原子 吸光光度計（パーキンエルマー 303 型）により $5890 \AA$ の波長で測定した。エステル 交換前の油 脂中のナトリウムの測定值を旨検值とした。結果 は Table-2 のとおりである。酸化度の低、No. 1 (POV 0), No. 2 (POV 4.4) は脱色処理により 除去されたが, 酸化度の高いNo. 4 (POV28.8), No. 5 (POV 40.9) では脱臭処理後もいくらか残 留を認めた。

Table-2 $\mathrm{Na}$ found at various stages of refining in interesterified lards.

\begin{tabular}{c|c|c|c|c|c}
\hline & \multicolumn{5}{|c}{ Sample oil (number) } \\
\cline { 2 - 6 } & 1 & 2 & 3 & 4 & 5 \\
\cline { 2 - 6 } & $\begin{array}{c}\mathrm{Na} \\
(\mathrm{ppm})\end{array}$ & $\begin{array}{c}\mathrm{Na} \\
(\mathrm{ppm})\end{array}$ & $\begin{array}{c}\mathrm{Na} \\
(\mathrm{ppm})\end{array}$ & $\begin{array}{c}\mathrm{Na} \\
(\mathrm{ppm})\end{array}$ & $\begin{array}{c}\mathrm{Na} \\
(\mathrm{ppm})\end{array}$ \\
\hline $\begin{array}{c}\text { Oil washed with } \\
\text { water }\end{array}$ & 8.97 & 10.39 & 51.95 & 100.45 & 50.00 \\
$\begin{array}{c}\text { Decolorized oil } \\
\text { Deodorized oil }\end{array}$ & 0 & 0 & 0.12 & 0.51 & 3.68 \\
\hline
\end{tabular}

\section{$2 \cdot 7$ 脱臭処理における留去物の GC-MS}

脱臭処理 (水蒸気蒸留) により得た留去物をエーテル で溶解し, GLC 分析を行い2本のピークを観察した。 (Fig.-4)。島津 LKB-9000 ガスクロマトグラフ-質量 分析計を使用して Fig.-4の 2 本のピークについて質量 スペクトル (GLC カラム; Silar $5 \mathrm{CP}(2 \mathrm{~m}) 170^{\circ} \mathrm{C}$, イ

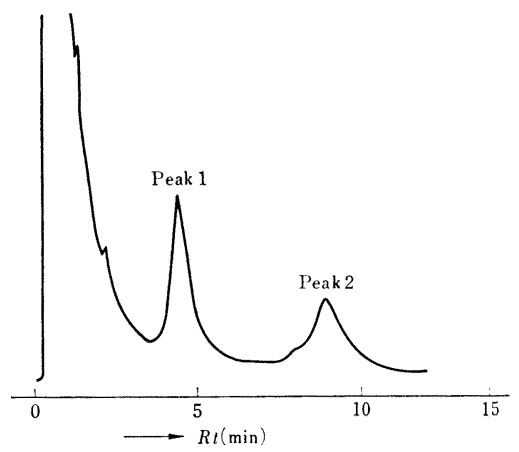

Fig. -4 Gas chromatogram of the distillate.

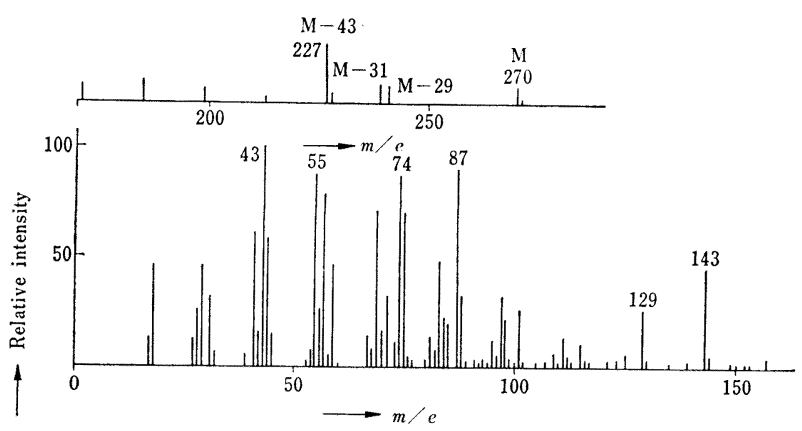

Fig. -5 a Mass spectrum of: Fig. -4 , peak 1 .

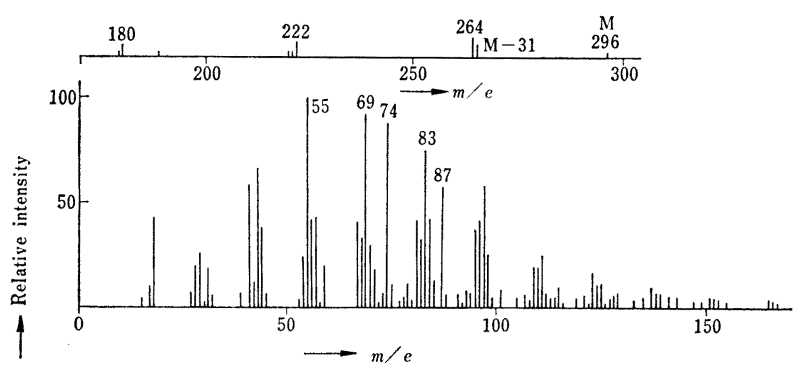

Fig.-5 b Mass spectrum of Fig. 4, peak 2.

オン化電圧 $70 \mathrm{eV}$, イオン源温度 $250^{\circ} \mathrm{C}$ ) を測定した。 その結果は Fig. -5 a, 5 b に示す。

Fig.-5 a は Fig.-4のピーク 1 の質量スペクトルを示 し, 特徵的なイオンピークとして分子イオン $\mathrm{M}^{+} m / e$ $270, \mathrm{R}-\stackrel{\mathrm{O}}{\mathrm{C}}-\mathrm{OCH}_{3}$ のエステルカルボニル 基に対する $\alpha$ 分解により生成した $\mathrm{R}-\mathrm{C} \equiv \mathrm{O}^{+}$，すなわち $m / e$ 239，力 ルボニル基に対する $\beta$ 分解物 $\mathrm{H}_{2} \mathrm{C} \stackrel{\text { 兵 }}{\mathrm{O}_{\backslash} \mathrm{OCH}_{3}}$ のm/e 74 や $\left[\left(\mathrm{CH}_{2}\right)_{n} \mathrm{COOCH}_{3}\right]^{+}$に相当する $m / e 73,87,101$, $115,129,143,157,171,185,199,213,227$ が観察さ れ，パルミチン酸メチルであることがわかった。また，

Fig.-5b は Fig.-4のピーク 2 の質量スペクトルを示し その特徴的なイオンピークは, 分子イオン $\mathrm{M}^{+} m / e$ 296, $m / e 264$ (M-32), m/e 222 (M-74), m/e 180 (M-116) 
等が観察され，二重結合をもつオレイン酸メチル ${ }^{111}$ の質 量スペクトルと類似のものであった。

\section{3 考察}

触媒としてナトリウムメトキシドを使用してラードの エステル交換を行った後, ナトリウムメトキシドの分解 及び反応生成物の残留の有無を調べた。GLCにより最 終精製処理, すなわち脱臭処理後のエステル交換油脂中 のメタノールの残留の有無を調べたがピーク注められ なかった。また各精製処理別の油脂中のナトリウム化合 物の存在を確認するため原子吸光光度法によりナトリウ ムを定量した。その結果, 酸化度の低、油脂では脱色処 理によりナトリウムが認められず, 酸化度の高い油脂で は脱臭処理後においてもいくらかの残留を認めた。脱臭 処理の際に得た捕集物質につきガスクロマトグラフ質量 分析計によって分析した結果はラードの主要脂肪酸であ るパルミチン酸及びオレイン酸のメチルエステルを同定 した。

Going ${ }^{2)}$ は油脂のエステル交換反応にお゙いて触媒とし たナトリウムメトキシドは加水分解を受けメタノール及 び水酸化ナトリウムを生じ, さらに油脂と反忘しセッケ ン及び脂肪酸のメチルエステルを生成すると指摘してい る。エステル交換反応後のナトリウムメトキシドは精製 の第一段階である水洗処理において加水分解を受けメタ ノールと水酸化ナトリウムとなり水溶性の両成分はこの 段階でほとんど除去され，またセッケンは著者らの上記 の結果, すなわち脱色処理によりナトリウムが大幅に減 少した事実によりこの処理により除去されているものと 思われる。脂肪酸のメチルエステルは精製の最終段階で ある脱臭処理により除去されていることを $2 \cdot 7$ の結果 は示している。もしもナトリウムメトキシドの加水分解 で生じたメタノールが水洗処理において完全に除去され
なかったとしても脱臭処理時に, 高沸点のパルミチン 酸メチル (bp $168.4^{\circ} \mathrm{C} / 5 \mathrm{mmHg}$ ), オレイン酸メチル (bp $212 \sim 213^{\circ} \mathrm{C} / 15 \mathrm{mmHg}$ ）が留去されることから前二 者よりも沸点の低いメタノール (bp $\left.64.5^{\circ} \mathrm{C}\right)$ も留去さ れるであろう。

一方, 油脂の酸化度が高くなった場合, 脱臭処理後も ナトリウム化合物が若干量残留したことは，親和性の関 係か，または新たな反応が生じた結果に上り招来したも のであるかは今回検討しなかった。

なお本報は昭和 51 年度油化学研究発表会 (東京) で一部発表 した。

\section{(昭和 52 年 7 月 20 日理)}

\section{文献}

1) M.W. Formo., J. Am. Oil Chem. Soc., 31, 548 (1954)

2) L.H. Going, J. Am. Oil Chem. Soc., 44, 414A (1967)

3) 中岡直砥, 光永新二, 島田哲夫, 岡田忠興, 特許公報, 昭 35-2885

4) 中沢君敏, 島田哲夫, 阊田忠興、油化学, 6 (3), 156 (1957)

5) L.H. Wiedermann, T.J. Weiss, G.A. Jacobson, K.F. Mattil, J. Am. Oil Chem. Soc., 38, 389 (1961)

6) T.J. Weiss, G.A. Jacobson, L.H. Wiedermann, J. Am. Oil Chem. Soc., 38, 396 (1961)

7) 張 堅二, 山内邦男, 津郷友吉, 日本食品工策, 16 (10), 446 (1969)

8）日本油化学協会制定, 基準油脂分析試験法, 2.4.19.2-71

9) H. Sano, M. Yamazaki, Agr. Biol. Chem., 40 (12), 2485 (1976)

10）農林水産技術会議事務局，食品分析研究会報告書，昭和 49年 6 月

11) G.R. Waller, "Biochemical applications of mass spectrometry” edited by G. Odham and E. Stenha. gen, Chapter 8. (1972) Wiley-Interscience, New York 